\title{
'Hunting licence' for drugs
}

\section{Ithaca, New York}

A CORNELL University chemical ecologist and a group of Costa Rican conservation biologists have pulled off a novel deal to finance the preservation of biodiversity in that Central American country.

As announced last Friday (20 September), the pharmaceutical giant Merck \& Co. has agreed to pay $\$ 1$ million over the next two years for the opportunity to screen thousands of unexplored plant and invertebrate species for biologically active molecules that could yield a host of new drugs. The 'hunting licence fee' will go to Costa Rica's Instituto Nacional de Biodiversidad (INBio), a non-profit agency established in 1989 to produce a complete biological inventory for the coun-

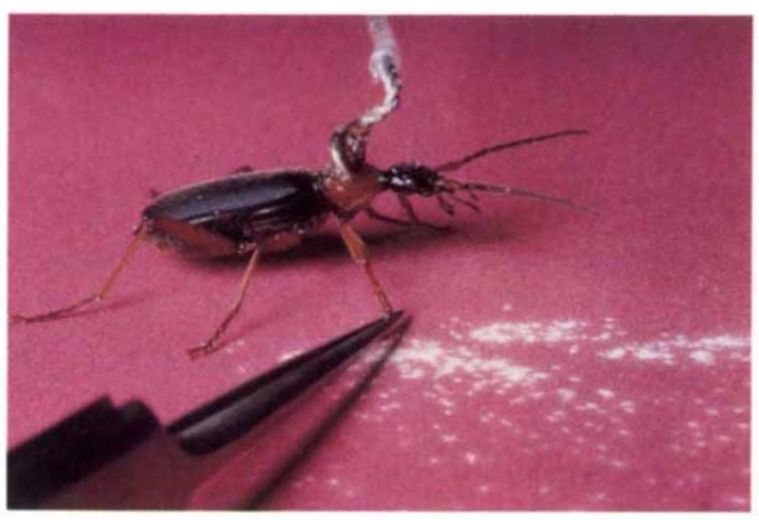

A tethered carabid beetle discharging its acid defensive spray on chemical indicator, in response to an 'attack' (pinching leg with forceps).

try - a decade-long, \$50-million effort expected to involve the cataloguing of an estimated 500,000 species, most of which are still unknown to science.

Part of Merck's fee will be passed directly to Costa Rica's ambitious conservation programme, under which more than a quarter of the country's land has been set aside as national parks and reserves.

The rest of the $\$ 1$ million will be used by INBio to fund 'chemical prospecting' for biological samples that might contain potentially valuable chemicals. In return, Merck will receive a certain number of samples, as well as exclusive rights to evaluate those samples for pharmaceutical and agricultural applications for a fixed period of time. INBio will receive royalties on sales of any products developed from these samples.

Pamela Adkins, a Merck official, said the company has several products now on the market that were derived from natural sources.

The agreement was conceived by Thomas Eisner, a biologist at Cornell University in Ithaca, New York, and Rodrigo Gámez, INBio's director. The money from Merck will help to train biologists and will pay for field searches for interesting plants and insects. At the same time, with a \$1-million, three-year grant from the MacArthur Foundation awarded last year, Eisner and Gámez plan to set up a programme to teach Costa Rican scientists the analytical side of modern chemical prospecting: screening for biological activity in a sample using known receptor molecules, then isolating and characterizing the active compounds. The intention is that INBio could eventually use money earned from chemical discoveries made in Costa Rica to finance the conservation of the country's tropical rain and dry forests.

But these financial returns lie many years away. Drugs may spend 20 years in development and testing and, as Eisner points out, a large area of tropical forest can be destroyed in that time. "If you really want to couple this to conservation, there has to be payment up front," he says. This is where the Merck agreement - which Eisner hopes will be the first of many comes in.

The first contact with Merck officials was made at a small conference at Cornell in October 1990, and Eisner says he was surprised at how little "conspiratorial thinking" on the part of himself and Gámez was needed to get the company interested in his idea.

In reconciling commerce and conservation, the Merck agreement seems to offer an appealing new way to finance the preservation of biodiversity. But Eisner's plan for Costa Rica has not been unanimously welcomed by his chemical ecologist colleagues. In particular, Timothy Johns, from McGill University in Canada, has dismissed Eisner's approach to conservation in print (Chemoecology 1, 142; 1990) as "doomed to failure", because it concentrates on the work of centres such as INBio, rather than involving the local population.

Eisner, who has long been an active campaigner for human rights in Latin America and elsewhere, is sensitive to any suggestion that his plan ignores or exploits local people. But he says that Johns' alternative approach - following up on traditional uses of natural products in developing countries to discover useful chemicals - is simply out of date. Using new receptor-molecule-based chemical screening techniques, many thousands of samples can be screened for biological activity each week, removing the need to rely on such 'ethnobiological' leads. Drug companies have little incentive to invest large sums of money in the sort of programme that Johns would like to develop, Eisner believes.

In any case, Gámez argues that Costa

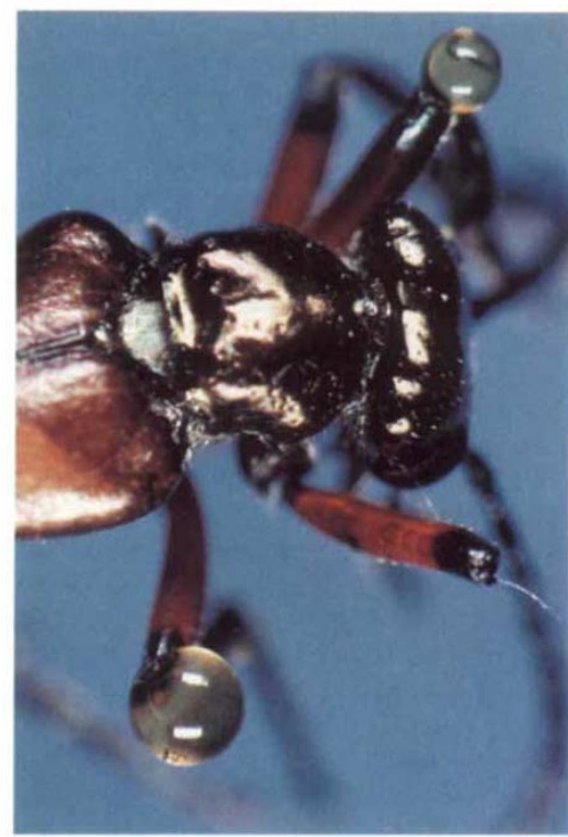

Blister beetle with droplets of blood emerging from its knee joints. The droplets contain chemical defensive agents, including the well known substance cantharidin.

Rica's conservation programme does involve local people. The country's national parks and reserves are managed by seven regional bodies, which encourage local people to participate in decision making, he says. INBio is also employing 'parataxonomists' - ordinary people, including high school graduates and housewives, who receive a six-month crash course in taxonomy at INBio before returning to their home towns and villages to work on INBio's inventory in the field. Gámez notes that these people also have an important role as educators in their local communities.

Although Merck's analysis of the Costa Rican samples will initially be based in the United States, Eisner says the training programme that he and Gámez are developing should eventually lead to homegrown screening in Costa Rica. He estimates that 25 drug discoveries are likely over the next decade from Costa Rica's plants and invertebrates - and if Costa Rica eventually receives significant royalty payments from just a few of these, the impact in a country whose entire national budget is less than those of some US universities would be huge.

Nevertheless, Eisner accepts that the Merck agreement might not work in all tropical countries. Costa Rica has a stable, democratic government, and a programme of conservation and cataloguing of its biodiversity that is already fairly advanced - all factors that were attractive to Merck, but absent from many developing countries. Eisner believes that the agreement, if successful, could provide a powerful incentive for other nations to mimic Costa Rica's land use policies in order to attract similar investment.

Peter Aldhous 